\title{
Jesus Revealed: The Dynamics of Early Christian Mysticism
}

\author{
APRIL D. DeConick
}

Like its sibling Judaism, Christianity understands itself as a revealed religion, as a religion that was not only disclosed through direct and immediate divine-to-human communication, but whose dogma reveals to humans the Hidden God and his will. With such a selfidentity, mysticism can scarcely be far away. Yet early Christian mysticism traditionally has been understood as a relatively late Platonic and philosophical product of patristic theology, marked particularly by Denys the Areopagite who, in the late fifth century, taught the apophatic way, where the soul escapes the created order to unite with the Unknowable God. ${ }^{1}$ The first generations of Christianity and their foundational memories and narratives are casually brushed aside as "background" to a mysticism arising later from Christianity's fusion with neo-Platonism. ${ }^{2}$

Although it is true that a particular strand of Christianity fused with neo-Platonism produced the type of mysticism taught and practiced by Denys, it is also true that long before Denys lived there was a rich tradition of Christian mysticism already in place, a mysticism that grew out of even older Jewish mystical traditions as I have described elsewhere. ${ }^{3}$ It was this Christian brand of early Jewish mysticism that was the root structure which produced and sustained the new movement. It was this Christian brand of early Jewish mysticism which eventually yielded a pliable branch for a neo-Platonic graft to take hold, such as it did in the teachings of Denys.

In many ways we are dealing here with the problem of semantics. When historians of Christianity talk about mysticism, it is defined by them in such a way that it explains a certain data set, particularly,

1 Louth 1981: 159.

2 Louth 1981. Cohn-Sherbok-Cohn-Sherbok 1994. Although McGinn does not wish to neglect the Jewish origins of Christian mysticism, his treatment of the Jewish materials hinges on fourteen pages before turning to a discussion of the Greek materials: McGinn 1992: 9-22.

${ }^{3}$ For a treatment of the major characteristics of early Jewish and Christian mysticism, see DeConick 2006b: 1-24. 
the medieval Christian monastic one, where the devotee through monastic practices gradually purges the darkness from the soul, experiences a spiritual death, ascends and unites with a god who is described as "love."4 There is a need for a definition that is less culturally-specific and less historically-descriptive than the Christian monastic one, a definition which will open up the exploration so that the texts themselves (rather than the definition) will be allowed to circumscribe the specifics of the phenomenon.

For comparativists who study mysticism across different religions, it is essential to operate with a less culturally and historically restrictive definition, such as mysticism is the direct experience of the Ultimate Reality. ${ }^{5}$ This type of comparative definition appears to have grown out of the psychological and philosophical work of William James, who divorced the mystical experience from the mystical praxis. James used the term to describe what was, for him, the core of religion - a unitive individualistic religious experience of the Absolute that produces an altered state of consciousness and leads to a change in the person's awareness and orientation. These experiences were not sought through an established praxis, but rather came upon the individual unbidden. ${ }^{6}$ This separation of experience from praxis is useful on one level because it keeps the conventional monastic definition from circumscribing the specifics of the phenomenon. But it poses analytical problems on another level, when we want to recognize a praxis that might be involved. So I recommend working with a more nuanced understanding of mysticism, such as mysticism is the solicitation and participation in a direct immediate experience of the Ultimate Reality. Although I would distinguish mysticism from the mystical experience itself, which is the direct immediate experience of the Ultimate Reality solicited or not, I would do so only with the full recognition that the mystical experience is the heart and soul of mysticism. It is so critical, so central, that mysticism would not exist without it.

What if we were to set aside the Christian monastic definition of mysticism momentarily and begin to examine, those claims to immediate and direct premortem experiences of God found in the early Christian sources, especially the foundational ones? What type of mysticism would we recover? What specifics would emerge? What would we find that makes it characteristically Christian?

${ }^{4}$ Cf. Underhill 1911; Egan 1996: xvi-xxv.

${ }^{5}$ Cf. Carmody-Carmody 1996: 10-14. Even some of these comparative treatments reflect and favor the Christian monastic ideal: cf. Happold 1963: 18-122; Johnston 1995.

6 James 1911. 


\section{Apocalyptic Experiences}

To describe their direct immediate premortem experiences of God; the early Christians did not use the word "mysticism," which derives from the Greek word myeô, "to be initiated." Although they do sometimes speak of the revelation of "mysteries" (mystêria), the first Christians call their direct immediate premortem experiences of God "apocalypses" (apocalypseis) or "revelations." The most famous but not the earliest example comes from the last book in the New Testament canon. The elaborate detailed visions of the heavenly realm and the descriptions of eschatological events given to John of Patmos are described as "the revelation of Jesus Christ."7 As such, this biblical book mimics the form of other contemporary Jewish apocalypses, in which the otherworldly journeys of various seers are described. It is characteristic of the apocalypse as a genre to focus on two dimensions of the revelation: the immediate premortem journey, ascent, or vision of the seer; and the revelation of secret knowledge particularly as it pertains to world events and cosmic endings. ${ }^{8}$

Among the early Christians, the claim to apocalyptic experience reaches far beyond the production of a "new" Jewish apocalypse like Revelation. In Paul's letter to the Galatians, he writes that he does not preach a gospel learned from another person. He received it "through a revelation of Jesus Christ." In fact, he bases the authority of his apostleship and mission on this experiential claim. Paul describes in another letter a typical Jewish mystical ascent journey in which "a man in Christ fourteen years ago" ascended to the third heaven where Paradise was located, and he heard the secrets that cannot be told. ${ }^{10}$ Was this the "revelation of Jesus Christ" that he had referred to in his letter to the Galatians? Paul certainly introduces the story as an example of the ongoing "visions and revelations of the Lord" which he boasts of for himself. ${ }^{11}$ So if it was not his initial vision, it may well represent one example among many that Paul claimed to have had. When stories about Paul's initial revelation are recounted in secondary sources like Acts, it is imagined by the storytellers in visionary and auditory terms, although not ascent. ${ }^{12}$ In all descriptions, it is an event of rapture rather than intentioned invasion.

\footnotetext{
${ }^{7} \operatorname{Rev} 1: 1$.

${ }^{8}$ Cf. Rowland 1982.

9 Gal 1:11-12. Cf. Segal 1990.

${ }_{10}$ Cf. Morray-Jones 1993a and Morray-Jones 1993b.

112 Cor $12: 1-4,7$.

12 Acts 9:3-8; 22:4-16; 26:9-18.
} 
The author of the letter to the Ephesians mentions that he has written previously about his revelation, which made known to him a mystery that had been hidden away until it was revealed to the apostles and prophets via the Spirit. He claims that it is his job now to make everyone see this mystery, which has been hidden in God for the ages. This mystery, the wisdom of God, is Christ the Power, who is described as the fullness of God beyond measure. This revelation is experiential between the believer and God, involving the inner workings of the Spirit who effects the indwelling of Christ and his love. ${ }^{13}$ The mystery is so profound, the author explains, because it means that Christ and his church are wedded lovers, a point that may be developing the assertion that Paul himself betrothed the Corinthian congregation to Christ as a pure bride to her husband. ${ }^{14}$

This testimony from Ephesians aligns with Paul's claim that his revelatory experience was an experience he thought all Christians would ultimately share. Paul sees this shared revelation as immediate and ongoing, as well as futuristic and eschatological, describing those in his congregations as people who are "expectantly awaiting a revelation of our Lord Jesus Christ." ${ }^{15}$ The author of Hebrews too writes that Christ will appear a second time, not to deal with sin (since he already did this when he sacrificed himself), but for the salvation of those who are expectantly awaiting him. ${ }^{16}$

These immediate and ongoing revelatory experiences were conceived by Paul to be constant gifts of the Spirit given to the community, gifts which were to be openly shared at church gatherings, together with the congregants' other prophecies, teachings, and hermeneutics. ${ }^{17}$ Ephesians preserves a prayer addressed to "the God of our Lord Jesus Christ" who is "the Father of the Glory," that he may grant the Spirit of revelation for the enlightenment of the minds of the believers so that they may know the riches of their glorious "lot." This "lot" is possible because of the greatness of God's power, which raised Christ from the dead and exalted him to the heights, Christ whose body is the church, the pleroma of God who fills everything. ${ }^{18}$

Paul understands himself to be a servant of Christ and a steward of the mysteries of $\mathrm{God} .{ }^{19} \mathrm{He}$ imparts to believers the hidden wisdom

13 Eph 3:3-19.

14 Eph $5: 32 ; 2$ Cor $11: 1-2$.

151 Cor 1:7.

16 Heb 9:27-28.

171 Cor $14: 26 ; 2$ Cor $14: 6,26,30$.

18 Eph 1:16-23.

191 Cor 4:1. 
of God in a mystery. Had this mystery been known to the "archons," they would not have crucified the Lord of Glory, he says. This is the mystery that no eye has seen, nor ear heard, nor mind conceived, except for the believers whom God loves. ${ }^{20}$ Paul insists that what has been invisible, ineffable, and inconceivable is immediately revealed to believers via the Spirit, while remaining unknown to the powers that rule this world. ${ }^{21}$

In'the Synoptics we find a similar tradition. The mystery of God's kingdom is given only to the believer, while the unbeliever sees without perceiving and hears without understanding. This teaching is framed as Jesus' own words. ${ }^{22}$ Related to these words of Jesus must be those other well-circulated words in which Jesus proclaims that what is hidden will be revealed, because there is nothing hidden that will not be made known. ${ }^{23}$ Quelle ("Q") records a prayer in which Jesus thanks the heavenly Father for hiding "these things" from the wise and revealing them to the babes. Jesus declares himself the Son who alone knows the Father and alone reveals the Father to those Jesus chooses. ${ }^{24}$

The idea that the "mystery" is "revealed" to Christians while simultaneously kept from unbelievers appears to have been a very old and prominent Christian teaching. Paul says that "the light of the knowledge of the Glory of God in the face of Christ" has shone in the hearts of believers, but it is kept from unbelievers. In their case, "the god of this aeon" has blinded their minds to keep them from seeing "the light of the gospel of the glory of Christ who is the Image of God." ${ }^{25}$ Only the believer is able to behold face-to-face the Glory of the Lord, and be gradually transformed into that Glory by degree, while the unbeliever stares absently at a veil that conceals the splendor of the Glory. ${ }^{26}$ This transformation is a mystery that will be completed at the eschatological moment when death is swallowed up in victory at Jesus' return appearance. ${ }^{27}$ According to Colossians, our "life" is immediately hidden with Christ in God. When Christ appears, so will our "life." Then we ourselves will appear as glorified beings. ${ }^{28}$

201 Cor $2: 7-10$.

211 Cor 2:10.

22 Mark 4:11-12; Matt 13:11-17; Luke 8:10.

${ }_{23}$ Mark 4:22; Matt 10:26; Luke 12:2; GTh 5.1-2, 6.4-5; Ps. Clem. Rec. 3.13; Keph 65.

${ }^{24}$ Matthew 11:25-26; Luke 10:21-22.

25 Cor 4:4-6.

262 Cor 3:18.

271 Cor $15: 51-55 ; 1$ Thess 4:15-17.

${ }^{28}$ Col 3:3-4. 
Thus, in the Pauline traditions, the eschatological return of Jesus was framed as the last apocalypse, when Jesus would be revealed from heaven with his mighty angels in flaming fire. ${ }^{29}$ This teaching, like the revelation of what is hidden to believers, is cogent with the remembered words of Jesus, that on the day when the Son of Man will be revealed, God's fiery judgment will rain down from the heavens. ${ }^{30} \mathrm{His}$ revelation, in the other Synoptic narratives, is described as a vision of the Son of Man coming on the clouds of heaven in power and glory. ${ }^{31} \mathrm{~A}$ vision of the coming Kingdom of God is also anticipated..$^{32}$

In the epistle attributed to Peter, the immediate and ongoing nature of the revelatory experience of Jesus Christ takes the backseat to the eschatological revelation. The congregation is told that an immortal, pure, permanent "lot" is being kept for them in heaven, yet is ready to be revealed to them during the days of the eschaton. This yet-to-come "revelation of Jesus Christ" will bring with it "grace." What is this revelation? Since the congregants are praised for loving Jesus and believing in him even though they have not yet seen him, this immortal fate is delivered to them through some kind of vision, called here "a revelation of Jesus Christ."

The author of this letter is confident that this immortal fate had already been revealed to the former prophets, since they spoke about the sufferings of Christ and his glorification. This fate has already been preached to the congregants by their leaders. Under the influence of the Holy Spirit who was sent down from heaven, these leaders already had taught believers "the things that angels long to have a glance at," but it is only at the eschaton that the believers will be able to possess their immortal permanent fate, when Jesus is revealed to them in the skies. ${ }^{33}$

The Petrine letter concludes with the note that the author himself already shares in the Glory that is about to be revealed to the congregants. ${ }^{34}$ This personal claim relies on the well-known tradition that the glorified Jesus appeared to Peter in a vision following the crucifixion and that Peter's knowledge of Jesus' messiahship was revealed by God, not by flesh and blood. ${ }^{35}$

\footnotetext{
292 Thess $1: 7$.

30 Luke 17:30.

${ }^{31}$ Mark 13:26; Matthew 16:28; 24:30.

${ }^{32}$ Mark 9:1; Luke 9:27.

33 Pet 1:3-13.

${ }^{34} 1$ Pet 5:1.

351 Cor 15:5; Luke 24:34. Matt 16:17; cf. Mark 8:27-33; Luke 9:19-22. Cf. Ps-Clem Hom. 17.18.
} 
These mystical experiences were understood by the early Christians to guarantee the authority, legitimacy, and authenticity of the teachings of the leaders of the movement, a point which the Pauline author of Colossians tries to sink at least in terms of the visionary claims of his Christian-Jewish opponents. ${ }^{36}$ At the same time, the Christian-Jewish traditions preserved in the Pseudo-Clementine corpus, which understand Paul to be the Apostate, show sharp polemic against Paul's claims to visions and the authority granted to him because of those claims. ${ }^{37}$

When we track early Christian testimonies about their immediate, direct, premortem experiences of God, experiences which they call "apocalypses," we discover that these experiences were perceived to be effected via the Spirit which indwelled them and altered them. The experiences transmitted what was hidden with God, which was perceived by them to be the mystery of immortal life, and identified as the power of Christ. These experiences were ongoing and participatory, as well as eschatological. But first and foremost, they were visionary, with important auditory and noetic qualities involved as well.

\section{Jesus' Appearances}

Jesus' postmortem "appearances" are a common feature in the literature, although even the vision of him before his death as the Glory is preserved in the transfiguration stories and allusions to them. ${ }^{38}$ The Christians also preserved traditions of apostolic visions associated with Jesus' call of the disciples, his prayer in Gethsemane, and his crucifixion. ${ }^{39}$ Paul transmits the earliest tradition of postmortem visions, recounting that Jesus appeared (horaô) to Peter ("Rocky"), the Twelve, more than five-hundred brothers, James, all the apostles, and finally to himself. ${ }^{40}$

Paul speaks of his own ecstatic experiences as "visions and revelations of the Lord." 41 One of these visions involved a heavenly journey where he heard humanly ineffable utterances. ${ }^{42}$ He states in defense

\footnotetext{
${ }^{36} \mathrm{Col} .2: 18$

37 Ps. $=$ Clem Hom. 19.16-19.

${ }^{38}$ Mark 9:2-8; Matt 17:1-8; Luke 9:28-36; 2 Peter 1:16-18; Acts John 90.

39 Acts John 88-89; Gos. Sav. 114.60-61; Acts John 97.7-10; Apoc Pet (NHC VII, 3) 81.

401 Cor 15:5-8.

412 Cor 12:1.

42 Cor 12:2-4.
} 
of his own apostleship and by comparison to Peter ("Rocky"), the other apostles, and the brothers of the Lord, "Have I not seen Jesus our Lord?"43

The secondary descriptions of Paul's initial revelation provide embellishments that Paul himself never mentions. In one case, Paul hears a voice who identifies himself as Jesus, but sees nothing but blinding light. It is reported that those with Paul heard the voice, but saw no one. ${ }^{44}$ In another report, those with Paul saw the light, but did not hear the voice. ${ }^{45}$ In the third report, Jesus tells Paul that he appeared to Paul so that Paul would serve him as a witness to the vision of Jesus he has seen and to those future visions in which Jesus will appear to him. ${ }^{46}$ One such vision, reported second-hand by the author of Acts, is remembered as happening to Paul in the Temple following his Damascus experience and baptism. During prayer, he "fell into ecstasy" and saw the Lord, receiving a commandment from him to quickly leave Jerusalem and go far away to the Gentiles. ${ }^{47}$

The early Christian literature is filled with claims to waking and dream visions of Jesus-postmortem. On occasion, the epiphany leads to prostration, grasping at his feet, and worship. ${ }^{48}$ The experience sometimes includes a heavenly ascent. ${ }^{49}$ There are occasions where Jesus is viewed through an open heaven as an exalted angelic figure. ${ }^{50}$

It is through these visions of the afterlife-Jesus that certain admonitions, commandments, and (sectarian) teachings are delivered orally to the seer by Jesus. ${ }^{51}$ These words of Jesus serve several func-

431 Cor 9:1.

44 Acts 9:3-9; cp. Acts Thom 27: the Lord "appears" to a group of initiates, but they do not see his form, only hearing his voice, because they were not able to bear his light.

${ }_{45}$ Acts 22:6-11.

46 Acts 26:16.

47 Acts 22:17-21.

:48 Matt 28:9, 17; Luke 24:30-31; John 20:17 (?), cp. Matt 28:9; Rev 1:17; Ep. Apos. 12.

49 Ap. Jas. 15.6-30; Gos. Sav. 100:2-6, 113:1-16; Passion of Perpetua 4.8. Cf. 2 Cor 12:2-4.

${ }^{50}$ Acts 7:55-56; Rev 4:1-6:17; cf. Rev 11:19, Ap. John 1.30-33

51 Mark 16:9-14: Mary Magdalene, two walkers, the Eleven; Matt 28:9-10, 17: Mary Magdalene, the other Mary, the Eleven; Luke 24:13-31, 34, 36-49: two on road to Emmaus, Peter, the disciple-collective; John 20:14-29: Mary Magdalene, the Eleven, Thomas; Rev 1:10-18: John of Patmos; Gos. Pet. 10:39, 14:60: Roman soldiers guarding the tomb, Peter, Andrew, Levi; Gos. Mary 10.10-23: Mary; Ap. Jas. 1.30-35, 2.3435: James, Peter, the Twelve; Gos. Heb. in Jerome, de Vir Ill 2: James; Acts Thom. 1, 11, 27: Judas Thomas, bride and bridegroom, group of initiates before baptism; $E p$. Apos. 10-11: Sarah, Martha, Mary Magdalene, the disciple-collective, Peter, Thomas, Andrew; Gos. Sav. 100:36-51, 107:4-30; 113:1-16: John, the disciple-collective (?); 
tions. They give authority to the leaders of various Christian communities, particularly when Jesus' words directly commission them to preach the gospel and bequeath them with the spirit. ${ }^{52}$ His words are used to correct opinions that some Christians did not like and rebuke unwanted behaviors, especially targeting the opinion of earlier believers who understood the visions of Jesus' resurrected body to be visions of a ghost or spirit. ${ }^{53}$ They also are used to indoctrinate certain beliefs that were proving a challenge for conversion or adherence, such as the idea that the Messiah should suffer and die as a criminal. ${ }^{54}$ Christological indoctrination seems to have been a priority, so christological assertions are common. ${ }^{55}$ The words of Jesus delivered in visions are also words of comfort, particularly relevant at a time when the imminence of the eschaton and Jesus' return were being questioned. So we find in his words assurances of his continual presence in the community, eschatological predictions about judgment and resurrection, and other prophecies. ${ }^{56}$ One of the most significant functions that the words of Jesus have in the vision setting is as revelation of the "mysteries" to those perceived worthy of the mysteries. In these cases, Jesus often delivers sectarian teachings as postmortem sayings and mythological instruction. ${ }^{57}$ To provide extra legitimacy for his words, the seen-Jesus frequently commands the seers to write down the private revelations they have just received from him..$^{58}$

Herm. Sim 10.1.1: Hermas; Ap. John 1.30-2.25: John son of Zebedee; Soph. Jes. Chr. 90.15-17: the Twelve, and seven women; Ep. Pet. Phil. 134.10-17; Passion of Perpetua4.8, 10.8: Perpetua; Acts Pet. 5, 20, 21: Peter, Theon at baptism, sons of Zebedee, blind widows; Hippolytus, Haer 9.13.2-3: Elchasai; Codex Manichaicus Coloniensis (CMC) fr. 1: Mani.

52 Commissions: Mark 16:15-18; Matt 28:19-20; John 20:21, 23; Acts Thom. 1:1-2; Ep. Apos. 19, 30, 41-42, 46; Herm. Sim 10.4.1-4; CMC fr. 1; cf. Gos. Sav. 113.11-12. For Paul, see earlier discussion in this section. Bequests of the Spirit: Luke 24:49; John 20:22; cf. Ep. Pet. Phil. 140.8-10, 16-21.

${ }^{53}$ Resurrection: Luke 24:37-43; John 20:27-28; Gos. Sav. 107.4-38; Ep Apos. 11-12. Other: Mark 16:14; John 20:17, 29; Ap. John 2.9-12; Gos. Sav. 107.24-39; Ep. Apos. 11, 24; Ep. Pet. Phil. 135.7-8.

${ }^{54}$ Luke 24:25-27, 44-48.

${ }_{55}$ Rev 1:17-18; Gos. Heb. in Jerome, de Vir Ill 2; Ap. John 2.13-15; Ep. Apos. 10, 13, 16-17, 19; Ep. Pet. Phil. 134.17-18; Acts Pet. 20.

56 Presence: Matt 28:20; Ap. Jas. 2.22-26. Eschatological predictions: Rev; Ep. Apos. 16-18, 21, 25-29, 34-39, 43-44.Other prophecies: Ep. Apos. 31-33.

57 Postmortem sayings: Gos. Mary 10.14ff.; Ap. Jas. 2.29ff.; Gos. Sav. 107.39-52; Acts Thom 12; Ep. Apos. 43, 47-50. Mythological instruction: Ap. John 2.16ff.; Soph. Jes. Chr. 92.6ff.; Ep. Pet. Phil. 135.8ff. Sectarian teaching in general: CMC fr. 1.

${ }^{58} \operatorname{Rev} 1: 19 ;$ Ap. John 31:29-35; cf. Ap. Jas. 1.9-12, 29-32. 


\section{Christocentric Mysticism}

The mystical experiences of God reported and remembered by the early Christians are remarkable in the centrality they afford Jesus. Their mystical experiences are Christocentric. The afterlife-Jesus is the main object of their revelations, both immediate and future. When his afterlife appearance is described, it is variable, often even shifting in the same vision. He is unrecognizable when first encountered.59 Questions arise whether he is a spirit or ghost. ${ }^{60} \mathrm{He}$ is mistaken for a gardener, his brother Judas Thomas (known to be his Twin), and the apostle Paul ${ }^{61} \mathrm{He}$ is described as an old grey-haired shepherd. ${ }^{62} \mathrm{~A}$ slain lamb. ${ }^{63}$ A child.$^{64}$ Simultaneously he appears differently to two seers: as an elderly man bearded and bald, and as youth with a beard only beginning to grow. ${ }^{65} \mathrm{He}$ appears to people as they were able to see him: to the small as small, to the angels as angel, to humans as human, to his disciples in glory and greatness. ${ }^{66}$ Visions of him are associated with a blinding light. ${ }^{67}$ His body is resurrected or magnificently glorified, sometimes unbearably so ${ }^{68} \mathrm{His}$ immense height is mentioned. ${ }^{69} \mathrm{He}$ is perceived to be a great spectacular angel whose resemblance cannot be described. ${ }^{70} \mathrm{He}$ is the Paraclete-angel who appears like lightning, after the fashion of the frightening luminous angels reported in Jewish apocalypses. ${ }^{71} \mathrm{He}$ is a luminous "youth" who becomes an old man before being recognized in his triple form as Father-Mother-Son. ${ }^{72} \mathrm{He}$ is the angelic Son of Man fully robed with haiir of white and eyes of fire. ${ }^{73}$ One minute he is as tall as the heavens,

59 John 20:14; Luke 24:16.

60 Luke 24:37.

61 John 20:15; Acts Thom 11, 34, 39, 88; Acts Paul 21.

${ }_{62}$ Passion of Perpetua 4.8.

${ }^{63} \operatorname{Rev} 4: 6-8$.

${ }^{64}$ Acts John 88; Gos. Sav. 107.58-60; Acts Pet. 5.

65 Acts John 89; cf. Acts Pet. 21, where he appears differently to different blind widows.

66 Gos. Phil. 57.28-58.10; Acts Pet. 20.

67 Acts 9:3-9; 22:6-11; 26:12-18; 2 Cor 4:4-6; Soph. Jes. Chr. 91.10-16; Ap. John 2:1-2; Ep. Pet. Phil. 134.10; Acts Thom 27; Acts Pet. 21.

68 Luke 24:36-43; John 20:19-20, 24-27; Gos. Sav. 107.12-23; Soph. Jes. Chr. 91.10-16; Acts John 90 .

${ }^{69}$ Bk Elchasai in Hippolytus, Haer 9.13.2-3; Passion of Perpetua 4.8, 10.8; Herm. Sim 9.6.1; cf. Gos. Pet. 10.39.

${ }^{70}$ Soph. Jes. Chr. 91.10-16.

${ }_{11}$ CMC fr. 1.3, 24, 46-55.

72 Ap. John.2.1-15; cf. Acts Thom. 27.

${ }^{73} \operatorname{Rev} 1: 12-19$. 
naked with white shining feet, and the next he is a small man. ${ }^{74} \mathrm{He}$ is "Jesus Christ who is with you forever." ${ }^{17} \mathrm{He}$ is the polymorphic Jesus, appearing in many forms. ${ }^{76}$

Obviously these polymorphic descriptions of the afterlife-Jesus serve Christological functions. In some contexts, they communicate Jesus' transcendence over death, while in other contexts, they assert that Christ is not constrained by the material world. ${ }^{77}$ In some cases, these descriptions of the seen-Jesus are highly stylized, keying old scriptural passages to Jesus' appearance in order to make even more specific Christological statements. His appearances are described after the fashion of glorious radiant angels like the ones described in Daniel 10:5-9 and the Apocalypse of Zephaniah 6:11-15. His future appearances are imagined as Daniel's Son of Man coming on the clouds of heaven. ${ }^{78}$ Other prophetic texts flesh out the imagined details of this eschatological Jesus-vision. ${ }^{79}$

What is most significant about the Christocentric nature of the early Christian visions is how the vision of Jesus was understood to function as the visio dei. While God the Father remains shrouded and invisible, the afterlife-Jesus appears in his stead. Quite early in Christian literature, he becomes known as the "image of the invisible God," as the corporeal revelation of the Hidden God. ${ }^{80}$ His appearance on earth functions to make visible to human beings the invisible God who is inapproachable and hidden, a God whom no one has ever or can ever see. ${ }^{81}$ Jesus is conceived to be the "form" of God in which the "fullness of deity dwells bodily." 82 Jesus is the only one who has ever seen God, and thus the only one who can reveal.God. ${ }^{83}$ Visions of him reveal the Father. ${ }^{84}$

This Christology where Jesus' appearance is God's appearance is particularly developed in the Johannine material. ${ }^{85}$ The author understands that Jesus is God's Glory who pretemporally was the luminous Logos living in the bosom of the Father. As such he is the

\footnotetext{
74 Acts John 90.7-11.

75 Ap. John 2.1-15

${ }^{76}$ Act Thom 48, 153; Origen, Against Celsus 2.64.

77 Foster 2007: 1-34.

${ }_{78}$ Daniel 7:9-14, particularly the Septuagint version.

79 Munoa 2002: 303-325. Cf. Isa 13:10; 27:13; 34:2-4; Ezek 32:7; Zeph 1:14-16; Zech 9:14.

${ }^{80} \mathrm{Col}$ 1:15.

${ }^{81}$ Cf. 1 Tim 1:17, 6:14-16; 2 Clem 20:5; Herm. Vis. 1.3.4; Diogn 7:2.

82 Phil 2:6; Col 2:9.

83 John 1:18.

${ }^{84}$ John 14:9; cf. 12:45.

${ }^{85}$ DeConick 2001a: 107-117.
} 
only one who has ever or will ever see the Father. Christ is cast as the Glory in heaven, the manifestation of God seen by Isaiah and described by Isaiah as a throne vision of the "Lord:" 86

The Johannine author historicizes this Christology so that in real time, Jesus is God descended from heaven, God tabernacling with humans. ${ }^{87}$ The mysticism that asserts itself in the Gospel of John centers on the historical presence of the Glory of God in the person Jesus. The gospel opens with the community's claim that they have seen his Glory ${ }^{88}$ The Glory of Jesus is shown in his person, his signs and wonders, and his crucifixion. ${ }^{89}$ Jesus asserts that "the Father and I are one" and "believe me that I am in the Father and the Father in me." ${ }^{\prime 90}$ The person Jesus is the visible manifestation of the invisible God. ${ }^{91}$ This vision-centered revelatory Christology is extensively developed by second-century Christian theologians fond of the Gospel of John, such as Irenaeus of Lyons and Valentinian teachers. ${ }^{92}$

What made possible the kind of Christology where Jesus is apprehended as the visible body of God on earth? This understanding of Jesus was built upon two related scriptural complexes. One complex includes a number of passages about the weightiness or manifestation of YHWH, called his Glory (MT: kavod; LXX: doxa). ${ }^{93}$ The starting point for the framing of Jesus as the visible Glory appears to have been Exodus 33:20 when YHWH tells Moses, "You cannot see my face, for human beings shall not see me and live." In this foundational story, God replaces a direct vision of himself with a vision of his Glory's backside, rendering himself distinct yet indistinct from himself. Ezekiel 1:26-28 was tied in, since it describes Ezekiel's vision of God as a vision of the Glory of the Lord, a human-like form with a gleaming body encased in fire and enthroned in heaven. ${ }^{94} \mathrm{~A}$ number of other passages, which associate the revelation of the Kavod with the future restoration of Israel and God's Judgment, completed the complex. ${ }^{95}$ So the tradition complex that emerges focuses on the hiddenness of God.

${ }^{86}$ Isa. 6:1; John 12:39-41.

${ }^{87}$ John 1:1-18. DeConick 2001a: 109-132.

88 John 1:14, 16.

${ }^{89}$ John $1: 14 ; 2: 11 ; 11: 40 ; 12: 23,28 ; 13: 32 ; 17: 1,4-5$.

90 John 10:30, 14:11.

91 John 1:18.

92 Cf. DeConick 1999: 321-325; Irenaeus, Haer. 4:20; Gos. Truth 38.15; cf. Irenaeus, Haer. 1.1.1; 1.2.1-5; Clement of Alexandria, Exc. 6.1-7.1, 3, 5; 26.1; Gos. Truth 16.35-17.1; 19.1120.15; 24.10-15; 37.36-38.24; 39.4-10; Tri. Trac. 66.14-15, 67.17-19.

93 Fossum 1999: 348-352.

94 Quispel 1980: 1-13.

95 Isa 42:8; 43:6-7; 48:10-11; 58:8; 59: 19; 60:1-3; Ezek 28:22; 39:13, 21. 
Direct viewing of God will bring death to creatures who attempt to gaze upon him. So he manifests himself in a bodily form that is luminous, even angelic. The Glory and the Lord himself were indistinguishable. ${ }^{96}$ God manifests himself as his Glory enthroned in heaven and seen by the prophets. The Glory will be revealed in the last days when God's Judgment comes upon the world.

The second scriptural complex included a number of passages that mention the Angel of YHWH as the human-like divine being who bears the Name YHWH. ${ }^{97}$ Like the Kavod, the YHWH angel was understood to be interchangeable with God or operating with God's power and authority..$^{98}$ Likewise, the $\mathrm{YHWH}$ angel was associated with God's Judgment. ${ }^{99}$ Consequently in the period Jewish literature, it is common to find Kavod-like angels sitting on heavenly thrones as the eschatological Judge and God's vicegerent. ${ }^{100}$

With reference to these scriptural complexes, Jesus was associated with the Glory. He was framed as the anthropomorphic manifestation of God and the Angel of the Lord, who bore God's Name and Image. ${ }^{101}$ It was in this way that Jesus became understood as the visible image of the invisible God. So visions of Jesus were powerful mystical experiences of God himself, experiences that were understood by the early Christians to be life-altering and (apo)theophanic.

\section{4. (Apo)theosis}

Although the visions of Jesus appear to have fulfilled a number of social and religious functions among the Christians who reported them, at the heart of the "revelation of Jesus Christ" was a soteriological assertion. The mystical encounter with Jesus transfigured the seer. A Christocentric (apo)theosis took place. The Gospel of Philip phrases it succinctly: "You saw Christ, you became Christ...What you see, you shall become." ${ }^{102}$

96 Ezek 9:3-4.

97 Exod 23:20-21.

98 Gen 16:7; Exod 3:2-7. Gieschen 1998: 51-69.

99 Zech 3:1-7; Isa 66:15-16; Mal 3:1-5.

1001 En 45:3, 55:4, 61:8, 62:2, 69:29; T. Ab. Rec A 11:4, 12:5; Apoc. Abr. 11:3. For Metatron references, see Orlov 2005.

101 Fossum 1995. Cf. Matt 18:20, 28:19; John 1:12, 2:23, 3:18, 5:43-33; 10:25; 14:10-13; 12:28; 15:21; 17:6, 11, 26; 20:31; Acts 2:17-21, 38, 5:41, 9:14, 16; 15:26; 21:13, 22:16; Phil 2:9; James 2:7; Heb 1:4, 13:15; Rom 10:9-13; 1 Cor 1:2; 2 Tim 2:22.

102 Gos. Phil. 61.30-31, 34-35. 
The basis for this assertion is the ancient belief that there is an actual identification of the seen-object with the seer. This belief is linked to ancient physiological knowledge about the operation of the eye. As early as Plato, we find the suggestion that the vision of an object touched the eye and then was transmitted to the psyche or soul. The vision of the object was imprinted on the soul like a stamp of a signet ring on a block of wax. ${ }^{103}$ This belief underpinned the piety and performance of the Greek mystery religions which celebrated the epopteia, the vision of sacred objects and the god or goddess enshrouded in light, as well as the Greco-Egyptian "way of immortality" known as Hermetism, where the process of (apo)theosis is achieved via visions of the self as Mind.$^{104}$ This Hellenic idea so penetrated the culture of the ancient world that it was considered common knowledge among the ancients and needed no explanation.

In our earliest Christian literature, Paul embraces the vision of Jesus Christ as life-altering, straight down to the convert's core being. Paul writes in 2 Corinthians 3:16-18 that at conversion a veil is lifted off the convert's face. With unveiled faces, Christians look into a mirror and see that their own reflections are the Glory of the Lord, that they are being transformed into his Image by degrees of glory. Paul says that this gradual transformation into the Glory is made possible through the power of the Spirit of the Lord, who indwells the faithful. He mentions in another letter that now we see dimly in a mirror, but there will be a time when we will see "face to face" and have full knowledge. ${ }^{105}$

Since Paul had identified God's Spirit as the spirit of Jesus Christ, he understood Christians as those people who, because they were possessed with his spirit, had taken on "the same form as the Image of his Son." ${ }^{106} \mathrm{He}$ addresses the struggling Galatians as a congregation he is suffering with "until Christ is formed in you."107 Paul claims that because Christ dwells in him, he has been crucified with Christ. "It is no longer 'I' who live," he says, "but Christ who lives in me." ${ }^{108} \mathrm{He}$ applies this same rationale to other Christians, explaining that if the Spirit of Christ is in them, although their bodies are dead due to sin, their spirits are alive due to righteousness. ${ }^{109}$

103 Plato, Theaet. 191a-196c. Cf. Achilles Tatius, Leuc. Clit. 5.13.

104 DeConick 2001a: 42-49; DeConick 2005: 210-211. Cf. Disc. 8-9 57.6-7, 33-58.22, 25-29, 60.25-61.2, 63.10-11.

1051 Cor 13:12.

106 Rom 8:29. Cf. Gal 4:6.

107 Gal 4:19.

108 Gal 2:20.

109 Rom 8:9-10. 
Paul commands people to be transformed by the remaking of their minds. Paul explains that we are to be remade in full accord with Christ Jesus and of one and the same mind with him, because "we have the mind of Christ" indwelling us. ${ }^{110}$ According to 2 Corinthians 5:17, "If anyone is in Christ, he is a new creature. The old has passed away, behold, the new has been made."111 Similarly, Colossians 3:9-10 reads, "You have put off the old humanity with its practices and have put on the new which is being remade in knowledge according to the Image of its creator."

For Paul, this gradual ongoing process of (apo)theosis via Christ would not be completed until the eschaton when the glorified body would ultimately replace the flesh as the fulfillment of the promise of the resurrection. The glorified body was the body resurrected, which was the Image of the man from heaven, Christ Jesus. ${ }^{112}$ Paul taught his parishioners to wait for "the Lord Jesus Christ, who will change our lowly body to have a form like his glorious body, by the power which enables him even to subject all things to himself."113

The (apo)theosis that Paul experiences as ongoing (and expects in the future) is possible not only because the visionary is identified with the seen-object as the faithful peer at the Glory in the mirror. There is a possessive dynamic involved too, where the embodiment of the spirit of Christ Jesus results in identification with him. Since he is YHWH-Manifest, the Glory of the Lord, and the Image of the invisible God, the indwelling of his spirit has a very powerful transformative effect on the possessed. Its residence within the believer works to transfigure the believer into that very same Image of God. The believer is glorified by degree, until the glorification is fully actualized at the eschaton when the transfiguration into a spiritual or resurrected body is finalized. Once all believers are. Images of God like Christ and the last enemy, death, is destroyed, Paul can say that God finally will be "all in all."114

Even though there are different emphases featured, the Johannine tradition is very similar to the Pauline in respect to its understanding of Jesus as God-manifest on earth. While Paul emphasizes that Jesus is the manifestation of God, the Johannine tradition emphasizes that Jesus is the manifestation of God. This difference in emphasis has caused some confusion in scholarship and the advancement of

\footnotetext{
110 Rom 12:2; 1 Cor 2:16; Philippians 2:1-5

111 Cf. Gal 6:15.

1121 Cor 15:42-49.

113 Phil 3:20-21.

1141 Cor 15:23-28.
} 
the flawed opinion that Paul is advocating "Christ mysticism" which centers on the Christ as distinct from God the Father, while John is focusing on "God mysticism" which does not have such a distinction. ${ }^{115}$

But this is not the case. For Paul the most significant part of the Kavod Christology is that Jesus is where God has been manifested and localized. If we conform ourselves to Jesus, we experience a similar (apo)theosis and localization of God. The Johannine author wants to stress the second half of that equation - Jesus is God revealed on earth. Because of this emphasis, he makes very explicit that, during the lifetime of Jesus, the historical vision of him was the vision of God. ${ }^{116}$ Even the angels in heaven must descend to earth to see the manifestation of God which is located in the historical figure Jesus! ${ }^{17}$

As a visio dei, the vision of the historical Jesus according to John was immortalizing: "For this is the will of my Father that everyone who sees the Son and believes in him should have eternal life."118 The Father is "in" Jesus and Jesus is "in" the Father because Jesus is the Glory. This Glory can be transferred to the disciples so that they too can be "in" Jesus and God, so that all of them can be "one." How does this happen? Jesus prays that they may see Jesus' Glory since the Father remains unknown. He will manifest the Father's Name and love to them, so that Jesus can be "in" them. ${ }^{119}$

How do you go about "seeing" Jesus after he is dead and gone when the author of John is very clear that flights to heaven are prohibited? ${ }^{120}$ Like Paul, the Johannine author understands that the Spirit of Jesus plays a role in the Christian community. Since Jesus is gone, the Spirit replaces the historical Jesus as God's manifestation on earth. The author calls this sent-Spirit "another Paraclete," implying that the historical Jesus was a previous Paraclete. So in Jesus' absence, the next Spirit of Jesus will be sent to abide with the community, manifesting himself as God's love in and among the faithful. ${ }^{121}$ This is worked out more fully in the Johannine epistles where it is stated that while no one has ever seen God, if we love one another, God lives in us. We can be certain, the presbyter writes, that "we live in him and he in us, because

\footnotetext{
115 Schweitzer 1931, 1953, 1998.

116 John 14:7, 9; DeConick 2001a: 113-121.

117 John 1:51. Cf. Rowland 1984.

118 John 6:40. Cf. 14:19.

119 John 17:20-26.

120 John $1: 18 ; 3: 13 ; 5: 37 ; 6: 46$.

121 John 14:16, 18, 22-23.
} 
he has given us his own Spirit."122 It was also used by Montanus as an explanation for the ecstasies that he and his prophetesses Maximilla and Priscilla experienced: he had been possessed by the Spirit and was the voice of the Paraclete sent by Jesus after his death. ${ }^{123}$

At the end of the Johannine gospel, Jesus blesses with life eternal those who have "not seen" but "believe."124 Throughout the gospel, the concept of faith in Jesus is repeatedly linked with the visionary experience to the extent that faith and vision not only become correlative concepts, but faith replaces vision and functions as a form of transfiguring vision. ${ }^{125}$ This concept is developed in the Johannine epistles where it is stated that anyone who confesses that Jesus is the Son of God, "God lives in him and he in God."126

The transfiguring vision of Jesus, however, remains in play as an eschatological event too. According to the Johannine epistles, his appearance at the end of time will result in our ultimate transfiguration. Although the presbyter is confident that "we are God's children now," he is equally confident that whatever form we will take when "he appears" will be like him "for we shall see him as he is." ${ }^{127}$

The type of mysticism that is developed in the Johannine literature appears to be directly responding to and critiquing another form of mysticism familiar to the author of the Gospel of Thomas. ${ }^{128}$ Thomasine mysticism was an open-heaven mysticism, which encouraged the faithful to ascend to heaven and gaze upon the Living God and his Son before death in order not to die. ${ }^{129}$ The Syrian Christians who wrote the Gospel of Thomas transmit traditions about the ascent passage through the spheres, enjoying Paradise, throne room etiquette, visionary meetings with heavenly doppelgangers and the Living God and his Son, and transfigurations into the primordial Man.130 They will enter the kingdom when they have remade their bodies into God's image - "eyes in place of an eye, and a hand in place of a hand, and a foot in place of a foot, and an image in place of an image."131

\footnotetext{
1 John 4:12-13.

23 See Marjanen 2005: $198 \mathrm{n}$. 39 for discussion of the numerous sources.

124 John 20:29-31.

125 DeConick 2001a: 125-127.

1261 John 4:15.

1271 John 3:2-3.

${ }_{128}$ DeConick 2001a: 86-108.

129 Gos. Thom. 59. Cf. DeConick 1996; DeConick 2005: 212-237; DeConick 2008: 206221.

130 Gos. Thom. 15, 18, 19, 22, 37, 50, 59, 84, 114.

131 Gos. Thom. 22.
} 
In order to commune with the Living God and his Son, this particular Christian community had combined this open-heaven mys= ticism with a call to an encratic praxis to control the body of passions. This form of mysticism appears to have strong roots in early Alexandria, as evidenced by its later development in the works of Clement of Alexandria. ${ }^{132}$ Since it is likely that the Syrian Christians were in communication with the Alexandrian community via the missionary route that physically connected them, the mysticism that emerges in the Thomasine gospel probably developed in dialogue between their leaders and early Alexandrian teachers. ${ }^{133}$ The result was a practical theology that taught that the human being indwelled with the Spirit could conquer the body of passions, and through righteous living could recreate in its place the virtuous body of the prelapsarian Adam. It was believed that the person could ascend and reside in Paradise, and elicit visions of Jesus and God through an encratic regime and meditative praxis. Eventually this would bring the person face-to-face with his or her own GodImage, a vision that restored the soul to its original glorious state. This form of mysticism is a precursor to the mysticism that pervades later Eastern Orthodoxy. ${ }^{134}$

\section{Democratization of the Mystical}

One of the most fascinating dynamics of early Christian mysticism is the evidence for the "democratization" of the mystical via the establishment of sacraments that make the presence of God regularly available to all believers. Baptism, anointing, and the eucharist were all understood to affect the transformation of the soul and the integration of the Spirit and/or the Christ into the soul. As early as Paul, these rituals were understood to reintegrate the person into the divine immediately and ontologically. Baptism washed clean the person, making the person righteous and providing sanctification through the indwelling of the Spirit and the Name of the Lord Jesus Christ. ${ }^{135}$ Because the baptized have put on Christ, all gender, religious, and social distinctions are gone. ${ }^{136}$ Since the faithful were

132 DeConick 2005: 225-231.

133 DeConick 2005: 232-237.

134 DeConick 2008: 206-221.

1351 Cor 6:1-11.

136 Gal 3:27-28. 
baptized in one Spirit, they are now one body. ${ }^{137}$ This sacramental ideology appears to be an extension of the early stories about Jesus' own baptism and the gift of the spirit.associated with it. ${ }^{138}$

Paul develops this old baptismal theology by ruminating on the implications of being possessed by Christ's Spirit. If we have his Spirit in us and have become part of his body, then we have experienced everything that he experienced, including his death and resurrection. This is why Paul says that when the faithful are baptized into Jesus Christ, they are baptized into his death, are buried with him, so that they are also resurrected like him to walk a new life glorified. ${ }^{139} \mathrm{He}$ understands that we carry within our bodies the "transcendent power belonging to God" which is Christ's spirit. Accordingly, we carry within our bodies "the death of Jesus" so that "the life of Jesus may also be manifested in our bodies."140

Paul has a similar interpretation of the eucharist. He understands that drinking the blood of Christ and eating his body effects union with him. He claims that this operates on the principle that the person who eats the meat of the sacrificed animal is united with the god to whom that sacrifice was offered, whether Jews who make the offering on YHWH's altar, or the pagans who do so at the table of demons. ${ }^{141}$

The Johannine author knows that baptism and eucharist are powerful mystical experiences that bring God's presence to the faithful in lieu of the historical absence of Jesus. ${ }^{142}$ For this community, entrance into the Kingdom of God is dependent on "water and spirit" which effect a personal rebirth. ${ }^{143}$ Through baptism, Jesus as the Spirit becomes present for the initiate. He is the "living water" which wells up to eternal life. ${ }^{144}$ Furthermore, Jesus is the "bread of life" which has "come down from heaven." ${ }^{45}$ This bread is his "flesh" which, when eaten by the faithful, provides immortality to them. ${ }^{146}$ The same is true of his blood ${ }^{147}$ How does this work? The incorporation of a sacred substance as food unites the faithful with that sub-

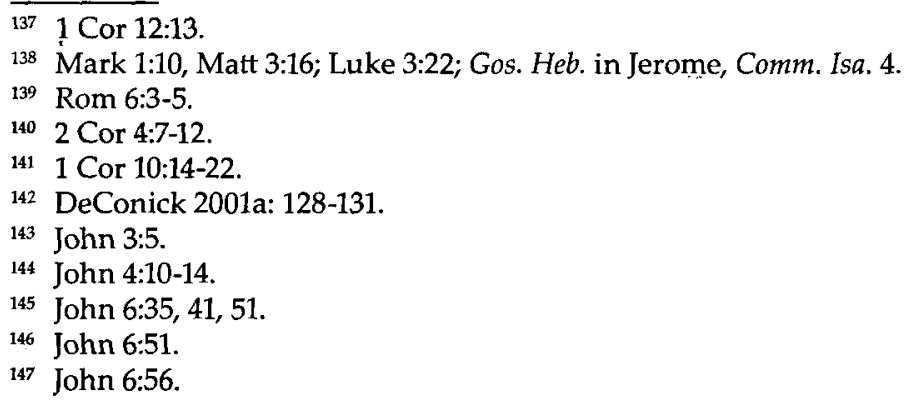


stance. So when Jesus' flesh and blood have been consumed, he has been incorporated into the person. ${ }^{148}$

The text is clear, however, that believers are not eating the flesh nor drinking the blood of the historical Jesus, because Jesus himself has ascended to heaven and his flesh had been transformed into a glorified body. What they are eating is something transfigured, something made divine via the Spirit - it is "flesh" made sacred by the descent of the spirit which joins with it during the ceremony in the same way that the Logos did at the incarnation. ${ }^{149}$ Because the Spirit is made assimilable via Jesus' divinized flesh and blood, the flesh and blood of the faithful who have eaten it mystically unite with him. By eating Jesus, his spirit is able to fuse with matter and begin the process of their own divinization. The incorporation of Jesus' sacred flesh results in the immortalization or resurrection of the flesh of the faithful who have eaten it.

In later traditions, this understanding of the eucharist persists. Ignatius understood it to be "the medicine of immortality" because it is the antidote for death, allowing the faithful "to live in Jesus Christ forever."150 Eating and drinking the flesh and blood of Christ unites the worshiper with him. ${ }^{151}$ Similarly Justin Martyr says that the incorporation of Jesus' sacred body nourishes and transforms our own flesh and blood into the flesh and blood of Jesus. ${ }^{152} \mathrm{He}$ also thinks that the occasion of the eucharist provides the faithful with a vision of Jesus as was prophesied by Isaiah, "Bread shall be given to him, and his water sure. A King with glory, you shall see." The act of the eucharist is conceived by Justin either to be itself a vision of Jesus or to prepare the faithful for a later vision of him. ${ }^{153}$

The Valentinians develop the mystical aspects of the baptismal and eucharist rituals in remarkable ways. In the first place, they appear to have performed a "second baptism" in order to bestow the Spirit. This ceremony involved anointing and, according to them, brought about their "redemption" by affording them the name "Christ" rather than merely "Christian"!154 Since Messiah or Christ means "anointed one," they argued that they are newly begotten as "Christs" by the Holy Spirit via the two baptisms (in water and with

\footnotetext{
148 John 6:56.

149 John 6:60-63. Cf. Schweitzer 1998: 274.

150 Ignatius, Eph. 20.

151 Ignatius, Phld. 4.

152 Justin, 1 Apol. 66.

153 Isa 33:16-17 LXX in Justin, Dial. 70.4.

154 Gos. Phil. 67.20-27.
} 
oil) when they are united with the perfect light of the Spirit. ${ }^{155}$ At the eucharist, they call upon Christ as the "Perfect Man" who is bread brought down from heaven to nourish the humans with the "food of Man."156 During the meal, believers receive Jesus" "flesh," which is Jesus" resurrected or transformed body known as the "Perfect Man." The cup is filled with the "Holy Spirit" belonging to the "Perfect Man." When the believer partakes in the eucharist, the believer receives the "Living Man" as clothing, uniting with the Perfect Man sacramentally. ${ }^{157}$ Thusly garbed in his body (which was invisible to the archons!), believers could anticipate an unhindered journey through the heavenly spheres at death in order to reunite with their angelic twins. ${ }^{158}$ The ritual appears to have effected some kind of immediate preliminary union with the divine self as well since the words of thanksgiving used in ceremony included this prayer: "O You who have united (with us) the perfect light as the Holy Spirit, unite too the angels with us, the images."159 Marcus' eucharist service also included a prayer petitioning immediate union with the angelic bridegrooms. ${ }^{160}$

The Christians believe that these rituals were effective because they relied on the power of the invocation of the secret Name of God (YHWH) which had been given to Jesus, a tradition that appears to be part of the foundational Christian movement known as early as Paul. ${ }^{161}$ The pronunciation of the Name effected forgiveness of sins, healing, and salvation. Its efficacy was based on principles common to ancient magic where appeals for intercession and healing were often made by employing the powerful secret names of deities and angels.

Speculation about the exalted Name given to Jesus and its secret permutations became the backbone of many esoteric Christian lodge movements. In Valentinian traditions, IAO was used as the secret

155 Gos. Phil. 69.5-15, 70.5-10.

Gos. Phil. 55:11-14. Cf. DeConick 2001b: 239-245.

Gos. Phil. 56:33-57:9; 70:5-10.

158

159

160

161

Irenaeus, Haer. 1.21.5; Gos. Phil. 76:23-30; 86:6-11.

Gos. Phil. 58.11-16.

Irenaeus, Haer. 1.13.3.

Phil 2:9-11; Rom 6:11; Eph 1:15-23; 2 Thess 1:12; Matt 10:22; 18:5, 20; 19:29; 28:19; John $1: 12 ; 2: 23 ; 3: 18 ; 5: 43-44 ; 10: 25 ; 12: 28 ; 14: 12-13 ; 15: 16 ; 16: 23-24,26 ; 17: 6,11,26 ; 20: 31$; Acts 2:14-38; 3:6, 16; 4:12, 17-18, 30; 5:28, 41; 8:12; 9:13-16, 21; James 2:7; 5:14; Heb 1:2-4; Rev 19:11-16; Didache 10.1; Gos. Thom. 13; 1 Clem. 58.1; 59.2; 60.4; Herm. Sim 9.14.5; 9.16.3-4; Justin, 1 Apol 61; Gos. Phil. 54.5-8; Gos. Truth 38.7-40.29; Clement of Alexandria, Exc. 22.4, 6-7; 26.1; 86.2; idem., Strom. 5.38.6-7; Mart. Ascen. Isa. 8.7; 9.5; Odes Sol. 39.7-8; 42.20; Acts Thom. 27, 163. Cf. Gieschen 2003: 115-158. 
password to gain access to the divine world. ${ }^{162}$ There is evidence that some Valentinians used Aramaic prayers that contained secret names of power associated with Jesus, including Messias and Nazarênos. ${ }^{163}$ Marcus the Valentinian claimed to have received the esoteric pronunciation and numerical meaning of the Name of Christ Jesus directly from the pleromic angel Aletheia who appeared to him in a vision. He is reprimanded for misusing the Name previously because he had been ignorant of its real power and meaning. ${ }^{164}$ Monoimus the Gnostic speculates extensively on the Name of the Son as "a single stroke," the letter iota. ${ }^{165}$ Sethian Christians chanted there own variations of the Name, including Iêieus and Iesseus Nazareus Iessedekeus, while also intoning various permutations of IAO. ${ }^{166}$ They complain about the misuse of the Name of Jesus by conventional Christians in their baptismal and eucharist ceremonies. ${ }^{167}$ The Naasenes and the Basilidians pass on the secret name of Jesus as Kaulakau which they derived from the Hebrew passage in Isaiah 28:10. ${ }^{168}$

This speculative tradition appears to have been known more generally among Christians who connected their investiture of the Name of Jesus with Ezekiel 9:4 where YHWH demands that his "mark" (taw) be put on the foreheads of the faithful. ${ }^{169}$ Since taw. is also the last letter of the Hebrew alphabet, the letter taiw was thought to be the mark of $\mathrm{YHWH}^{170}$ As the last letter of the alphabet, it was considered shorthand for the Name of YHWH. ${ }^{171}$ This Name abbreviation was familiar to the Christians who knew the LORD as the alpha and omega of the Greek alphabet, and Christ as "the first and the last." 172 Significantly, in ancient Hebrew script, a Hebrew taw looked like two crossed lines, which the Christians recognized as a cross. ${ }^{173}$ It is quite likely that the mark taw as the stauros was their understanding of the secret Name of Jesus put on the initiate at the time of baptism.

\footnotetext{
${ }^{162}$ Irenaeus, Haer 1.4.1; Epiphanius, Pan. 31.35.4.

163 Irenaeus, Haer 1.21.3; Gos. Phil. 56.4-15.

164 Irenaeus, Haer. $1.14 .4 ; 1.15 .2$.

${ }^{165}$ Hippolytus, Haer. 8.12.1-15.2.

166 Gos. Eg. III 66.9-22.

${ }_{167}$ Gos. Jud. 38.5, 26; 39.11-17; 40.4-5; 55.22-24.

${ }^{168}$ Irenaeus, Haer. 1.24.5-6; Hippolytus, Haer. 5.8.4.

169 Cf. Rev 7:2; 13:17.

170 Origen, Selecta in Ezechielem 9; Tertullian, Against Marcion 3.22; Shabb 55a.

171 Finegan 1978: 220-260.

172 Rev 1:8, 17.

173 Origen, Selecta in Ezechielem 9. Finegan 1978: 225, 228.
} 


\section{The Cosmic Drama Internalized}

A dynamic that cannot be overemphasized is the relationship that early Christian mysticism has with eschatology and the drama of cosmic endings that the Christian Jews anticipated to fully play out in their lives. This was a drama that depended on a standard Jewish myth about the nature of human beings and the predicament of human existence. Since the Genesis story teaches that God created human beings in his Image so that they enjoyed living directly in his presence, ancient readers speculated about what exactly happened that this was no longer the case and what actually needed to happen in order for it to be the case again. Most Jews thought that Adam had made a bad choice, which separated him from God, either tarnishing his original state or losing it entirely. This meant that piety was the key to restoration and salvation. If the person lived in obedience to God's Law, upon death or the eschaton, the person would be restored to the original created state as God's Image and live again in paradise. This they taught by way of their eschatological doctrine of the resurrection of the dead, the restoration of the person in a glorious angelic-like body reflecting God's Image. ${ }^{174}$

Some Jews felt that the lost Image could be restored, at least provisionally, before death - that paradise and its fruits could be had now. Literature from the Dead Sea, reports about the Therapeutae, and the writings of Philo demonstrate that some Jews were involved in communal practices to achieve this mystical transformation of the body in the here and now - the immediate inclusion of the faithful in the community of angels. ${ }^{175}$. What these people were doing is making present the eschatological encounter with God and all the promises that went along with that encounter, including the promise of the glorified body. This meant that the traditional rewards normally reserved for the Last Day became available to the faithful in the Now, including the revelation of God's mysteries and encounters with God that resulted in the devotee's immediate (apo)theosis.

It would not be correct, however, to envision mysticism and eschatology as oppositional in a combative sense. Rather they are twin dimensions of apocalypticism, better understood as opposite ends of the same continuum. In the case of eschatology, it views salvation and transformation on a cosmic level as a future apocalyptic real-

174 DeConick 2006b: 18-22; Segal 2004.

175 DeConick 2006b: 21 n. 66. 
ity. In the case of mysticism, it views salvation and transformation on a personal level as an immediate apocalyptic reality. Eschatology is mysticism externalized and postponed. Mysticism is eschatology actualized in the Now on a personal level, often internalized. Yet these two ways of viewing the human being's relationship to God do not work in opposition to each other, but together, even in tandem. Rarely, if ever in early Christian literature, do we find one without the other. The matter usually is one of focus or emphasis, whether the eschatological or the mystical dominates.

Thus we find in the earliest Christian literature both eschatology and mysticism operating seamlessly as partners, beginning with the early memories of Jesus. He is remembered as a prophet, anointed with the Holy Spirit. In this way, he is recalled as the exemplar mystic whom God's Spirit indwelled at his baptism and transfigured into a luminous angel on the mountain. A major focus of his teaching was the immediacy of God. He was remembered as a teacher who spoke about the future but imminent end of the world, when God's Judgment would occur and God's Kingdom would be established. Simultaneously, he was remembered as a teacher who informed his followers that God's Kingdom was already accessible to them, that it had been sown like a mustard seed in the earth. He had come to reveal to them directly and immediately what is hidden - the mystery of the Kingdom and knowledge of the Father.

This dual message allowed early Christian mysticism to develop in fascinating directions, especially when the immediacy of the eschaton was called into question after long years of waiting for an event that became the Non-Event. When the Kingdom did not come, the early Christians re-evaluated their traditions to explain the NonEvent and make meaningful again their remembrances of Jesus' apocalyptic words.

There were several strategies tried, and all of them were successful to some extent. Paul appears to have emphasized the fact that Christians were already experiencing a divine transformation as the result of the indwelling of Christ's Spirit at their baptism. Revelations of Christ Jesus should be expected as part of their contemporary experience. The transformation, however, would be fully actualized at the eschaton when the final revelation of Christ Jesus in the clouds of heaven occurred. Paul's solution was to understand the restoration to God's image progressively, as a number of stepping stones paving the way to the final moment of full actualization. In this way, both the mystical and the eschatological dominate the religious experience. 
The authors of the Synoptic gospels assure their readers that the eschaton will be a reality that must be prepared for regardless of when it will happen. It is rationalized in Matthew that not even the Son knows when it will come (so be ready and waiting!) and in Luke that it has been delayed in order to develop the church mission and fully engage proselytizing. In these cases, the eschaton is understood to be underway, although postponed. This meant that the cosmos was already experiencing alteration as the Kingdom or Church replaced the kingdoms of this world. The cosmos was changing as God or his Spirit broke into the world, making immediate and direct encounters between him and the faithful possible. But the restoration of the Image was reserved mainly for the day of the resurrection. This solution allowed the eschatological to dominate while the mystical simmered in the background.

The early Christians begin to consider the implications that Jesus was the first of those to be resurrected from the dead. Since this was the case, had the end of the world already started? Many of them thought so, which led them to view their own lives as eschatologically actualized. They were living in the era of the End, and all the promises of the eschaton were theirs already. With the collapse of their eschatological expectations, more and more they rely on the mystical dimension of apocalypticism. Some, like the Syrian Christians represented by the Gospel of Thomas, shift their theology away from an eschatology that is futuristic and cosmic to an immediate personal mysticism that hinges on pre-mortem ascent and vision garnered through an encratic regime that transformed their bodies and allowed them to invade Eden. ${ }^{176}$ The Johannine Christians went so far as to collapse back into the historical life of Jesus the future eschatological drama, so that the coming of the Son of Man, the Judgment, and the establishment of God's Kingdom already occurred during Jesus' lifetime. Although there is still an expectation of a future coming of Jesus and the final transforming vision of him, this takes the back seat to the teaching that already they have been judged, already they have been saved, already God has been revealed to them through Jesus and his Spirit. ${ }^{177}$ In this case, the mystical dimension trumped the eschatological and the cosmic drama was played out as an internalized pageant.

176 DeConick 2005.
177 John 1:12; 3:13, 17-21; 5:24; 6:62; 11:26. 


\section{The Mystery Uncovered}

The mysticism that pervades the foundational early Christian movement is Christocentric. It focuses on the "revelation of Jesus Christ" which is understood to be the disclosure of the mystery that has been hidden with God for the ages. What is the mystery revealed? That Christ Jesus is the Power and Fullness of God.

It was taught that all Christians experienced this revelation, whether in an ongoing or future manner. The experience began with baptism with the indwelling of the Spirit. It continued in the life of the community and the sacraments where Jesus and the Spirit were encountered regularly. Christ's ultimate revealing would be eschatological and visionary.

The revelation of Jesus Christ resulted in (apo)theosis, where the believer morphed into Christ as God's Image and (eventually) achieved the "lot" of immortality. This (apo)theosis was dependent on the fact that the revelation of Jesus Christ functions as a visio dei, where the vision of Christ Jesus substitutes for the vision of God. This theology was dependent on the tradition that YHWH is a hidden unseen God who manifests as the Kavod and YHWH Angel, beings which are essentially God's equivalents. Encounter with Jesus is encounter with God. And its effects on the faithful are life-altering. The faithful are transfigured into the same Image that Christ is, which means that they too become God-manifest. There is some speculation in the literature that the Father himself might be revealed eschatologically, but in the now it is Jesus as God's Image who is met by the faithful, and it is he that they become. 